\title{
The World of English Teachers in a Facebook Common-Interest Group
}

\begin{abstract}
In view of the fact that teacher discussions in professional online communities are not frequently researched, the author decided to conduct a small scale study with the aim to analyse discussions held by members of two Facebook groups for English language teachers. The findings show that members of both groups want to know how they could help their students, and discuss their own professional and personal needs. Moreover, members of both groups show their appreciation not only towards practical solutions, but also towards the theoretical content suggested by others. Furthermore, the analysis has revealed that language teachers need to be constantly motivated, inspired and reassured that they are doing their job well. Finally, the findings show that, apart from creating their own personal learning networks in Facebook groups, their members treat them as arenas for promoting their products, services, or events. Keywords: language teachers, Facebook groups, professional development, personal learning networks, self-promotion.
\end{abstract}

\section{Introduction}

Social media are a type of online communication during which its participants create, share and/ or exchange content, collaborate or network in virtual communities (Rouse 2016). Social media include, among others (Foreman 2017):

- social networks, for instance,

- LinkedIn, a social network for professionals who want to find new career opportunities (Nations 2018);

- Twitter, a site where people communicate in short messages called tweets creating a stream of quick updates from friends, family, scholars, news journalists, experts, etc. (Gil 2018).

- media sharing networks, for instance,

- Instagram, an application for sharing photos and videos from a smartphone;

- YouTube, a free video-sharing service where users watch, like, share, comment on, and upload any videos they deem to be interesting.

- discussion forums, for instance,

- Quora, a question-and-answer site;

- Digg, a news aggregator which features user-submitted news stories which are then voted up or down by the user community. 
- bookmarking and content curation networks, for instance,

- Pinterest, a web-based pinboard (Moreau 2018), where users save images they found on the Internet to different boards which are used to categorize one's collection of images;

- Flipboard, a platform which aggregates articles, video, and social media into a personalized digital magazine (Willson 2017).

- blogging and publishing networks. They include, among others,

- WordPress most popular tool for creating websites which range from simple blogs to professional business sites (Biglione 2016).

- Tumblr a microblogging platform. Each user has their own Tumbleblog where they can publish short texts, images, quotes, links, video, audio and chats (Gunelius 2018).

Interestingly, social media are have attracted attention of scholars from various disciplines: "From psychiatrists to education scholars, from biologists to mathematicians, it seems that the potential (and drawbacks) of social media are debated across disciplinary lines" (Velestianos 2016: 5).

In language education teachers are encouraged to make social media a teaching tool as children and teenagers frequently turn to them by default (Gibson 2012). According to Alrubail (2017), Instagram, Twitter, Facebook, Tumblr, and even Snapchat are used by students, and can be introduced to language classrooms to develop students' overall communication, micro-writing and writing skills with the emphasis on, for example, tone, writing conventions, and levels of formality (King 2017). Moreover, social media offer students a richer target language input, greater and more varied interaction and feedback opportunities(Golonka et al. 2014, in: Xodabande 2017), greater opportunities for meaningful and authentic language use than are available in the classroom (Richards 2015, in: Xodabande 2017), and promote autonomous learning of selected language aspects (Xodabande 2017).

However, apart from becoming an effective teaching tool, social media can support teachers in their professional development. For instance they can provide educators with a free, in the majority of cases, access to resources which teachers cannot afford or obtain due to financial and/or location constraints (Dede et al. 2009, in: Carpenter and Krutka 2015: 31). Furthermore, thanks to social media it is easier for teachers to combat the feeling of isolation (Hoskins 2015) and find partners for communication and collaboration (Vavasseur \& MacGregor 2008; Wesely 2013, in: Carpenter and Krutka 2015: 31): “(..) with such a wealth of opportunities to connect with and learn from fellow educators on platforms such as Twitter, it would seem to make sense to include social media in your professional development toolkit” (Hoskins 2015).

The aim of this article is to briefly characterize the largest social networking site in the world (Santos and Rogers 2012), i.e. Facebook, and its use in language learning and teaching, and to analyse in details the posts from two groups for English teachers to see what content theirmembers share, what questions they pose and what answers the seek and how all these issues reflect their professional and personal needs as well as their development as language teaching professionals. 


\section{Facebook in language teaching and learning}

Facebook was launched in 2004 and since 2006 anyone who turned 13 can create their own Facebook account. One of its best known features is the like button introduced at the beginning of 2009. Facebook members use it to show that they appreciate and support specific comments, pictures, wall posts, statuses, or fan pages (Rouse 2010). In 2006 Facebook introduced five more reactions buttons called "Love," "Haha," "Wow," "Sad," and "Angry." which "are meant to help its 1.44 billion users show empathy in the instances where leaving a 'like' may not feel like the most appropriate response" (Heath 2016).

Facebook's public features include (Rouse 2014):

- $\quad$ pages - they allow its users to create and promote a public page devoted to a specific topic;

- events - they allow Facebook users to create and publicize an event, invite audience and track who plans to participate;

- market place - it enables users to buy and sell items in their area;

- presence technology - it lets Facebook users see which contacts are online and chat with people they befriended;

- groups - they allow their members to come together around a common cause, issue or activity e.g. to organize events, share their opinions, look for and share advice, post photos or other related content (Black 2017). Groups can be set up and managed by any Facebook user and one person can join up to 6,000 groups.

Originally created for socializing, Facebook, just like other social media sites, is gradually being acknowledged by subject and language teachers who appreciate its value as a resource and sharing tool (Bissessar 2014: 122). Facebook has been used, for instance, to investigate whether it could help undergraduate students improve their English language proficiency, critical thinking, comprehension, skills, and motivation (Faryadi 2017), whether it could be integrated into a universitylevel English writing course (Yu 2014), whether it could support collaborative activities in higher education (Amasha and Alkhalaf 2014), or whether it could encourage learners' participation in information-sharing (Omar et al. 2012).

Language teachers can also use Facebook in simpler ways in language classrooms. According to Pappas (2013), the most professional way to establish online classroom community is by creating a Facebook page or group. Contrary to a page which can be accessed and liked by anyone, a group can become a more intimate place where students meet. To encourage stronger bonds and protect the privacy of its members the group should be "closed" (ibidem). In the first place, a Facebook group could be used asa 'broadcast' account (Britland 2012). This one-way communicationenables teachers, among others, to remind students about their homework assignments, upcoming deadlines, test dates, etc. (100 Ways To Use Facebook In Education 2017).

A Facebook group set up for the purposes of a given language course can also be used as a platform for sharing resources. Teachers can post links to, for instance, educational videos or concepts that students are currently discussing. A Facebook group can also become an archive of classroom 
materials that students can access when they missed class or want to revise before a test or exam (100 Ways To Use Facebook In Education 2017).

A Facebook group enables teachers to extend their classrooms and augments face-to-face interaction (Using Facebook in your teaching 2018). If a lively discussion is taking too much classroom time, students can be asked to continue it on Facebook, and the lesson can move on.

Apart from extending their classrooms and making learners more involved in their lessons, subject and language teachers use Facebook groups to socialize and cooperate with each other, to express their concerns, to search for and give advice, etc. In other words, teachers initiate and manage their own professional development in an online milieu (Van Bommel andLiljekvist 2015). As Bissessar (2014: 121) observes: "At the click of a mouse, teachers are communicating and receiving ideas on curriculum issues, improving their instructional delivery, design and methodology, dealing with classroom issues, discussing topical issues globally and regionally, disagreeing with each other, and improving their personal development".

Manca and Ranieri (2014) identified two main types of Facebook groups for teachers: generic and thematic. In generic groups teachers share their experiences related to education in general while in thematic groups they discuss specific issues, e.g. special educational needs. Interestingly, teachers who engage in collegial discussions and share their professional experiences on Facebook do it more publicly than in any other arena of professional discussion (Lantz-Andersson et al. 2017). Furthermore, teachers who seek but also share support, ideas and inspiration in Facebook groups create their personal learning networks (PLN). However, further discussion of this issue is beyond the scope of this article.

\section{The study}

Lantz-Andersson et al. (2017) argue that teacher discussions in professional online communities are still relatively unexplored. In the literature review on social media in teacher professional development presented by Greenhow et al. (2018) it is Twitter that seems to be the most frequently researched platform. Furthermore, there is a dearth of studies devoted solely to the role of membership in Facebook groups for English teachers and its significance for professional development. That is why a decision was made to conduct a small scale research project with the aim of analysing discussions held by members of two Facebook groups for English language teachers.

The following research questions were asked:

- What categories of posts can be found in the two groups?

- What is the content of the posts shared by members of both groups?

The analysed posts in the study come from two generic Facebook groups for English teachers, which were found through Facebook's internal search engine, with the search term "English teachers". In order to ensure the anonymity of their members, the groups will be labelled as group A and group B. As of April 2018, group A had 227972 members and 3 administrators, while group B had 95167 members and 5 administrators. To assess the activity of participants in the Facebook groups examined for the purposes of the study the author of the article joined both groups, but 
did not publish, comment, share, or like any of the posts over the duration of the study. The posts were gathered for the first two weeks of March 2018 and a total of 240 posts (120 posts from each group) were subjected to quantitative and qualitative analysis. The author decided against quoting posts directly to better preserve the anonymity of the group members.

\subsection{Analysis of the results}

\subsubsection{Categories of posts}

The author analysed the posts from the two groups (differing in size) to see if there are any differencesin the post categories. The analysis has shown that the groups share 8 similar categories but with a varied number of posts. The categories are: posts in which the members ask a language or teaching question, posts in which members share motivational posters for teachers, posts in which they look for pen pals for their students or project partners, posts where they publish different types of questionnaires, posts in which they share links to websites that might be of interest to language teachers, posts which are shared from other Facebook groups or personal or organizational pages, post with links to videos and posts with links to events such as workshops or conferences. Additionally, in group B (the smaller one) there is a group of posts in which members share posters explaining or illustrating in a visual way the meaning of different language expressions.

Table 1. Categories of posts in the analysed sample.

\begin{tabular}{|l|l|l|l|}
\hline Topics group A & Number of posts & Topics group B & Number of posts \\
\hline $\begin{array}{l}\text { 1. Asking for advice/ } \\
\text { asking a question }\end{array}$ & 27 & $\begin{array}{l}\text { 1. Asking for advice/ } \\
\text { asking a question }\end{array}$ & 24 \\
\hline 2. Links to websites & 29 & 2. Links to websites & 37 \\
\hline 3. $\begin{array}{l}\text { Posts shared from } \\
\text { FB pages/groups }\end{array}$ & 36 & $\begin{array}{l}\text { 3. Posts shared from } \\
\text { FB pages/groups }\end{array}$ & 19 \\
\hline $\begin{array}{l}\text { 4. Motivational } \\
\text { posters for } \\
\text { teachers }\end{array}$ & 4 & $\begin{array}{l}\text { 4. Motivational } \\
\text { posters for } \\
\text { teachers }\end{array}$ & 11 \\
\hline 5. Looking for pen \\
pals/partners
\end{tabular}




\begin{tabular}{|c|c|c|c|c|c|}
\hline & $\begin{array}{l}\text { Links to events/ } \\
\text { courses }\end{array}$ & 3 & & $\begin{array}{l}\text { Links to events/ } \\
\text { courses }\end{array}$ & 1 \\
\hline 9. & $\begin{array}{l}\text { Posters illustrating } \\
\text { meaning of words } \\
\text { and phrases }\end{array}$ & - & & $\begin{array}{l}\text { Posters illustrating } \\
\text { meaning of words } \\
\text { and phrases }\end{array}$ & 16 \\
\hline \multicolumn{2}{|c|}{ Total } & 120 & \multicolumn{2}{|c|}{ Total } & 120 \\
\hline
\end{tabular}

\subsubsection{Content of the posts}

\section{a)Asking for advice/asking a language question}

Professional development is, among others, an evolving process of self-disclosure, reflection and growth (Diaz-Maggioli 2003). For language teachers growth means, apart from the enhancement of all aspects of the person (Iannone 2017) and the development of teaching skills, also the improvement of their language skills.

Facebook groups are a good place to ask questions related to professional development, as contrary to participation in language or methodology courses, group membership carries no cost. Moreover, questions are usually answered quickly and pooled teaching experiences, skills and language knowledge of group members will probably not leave a problem unsolved.

The analysis of the posts has shown that overall questions asked by members of both groups can be divided into the following categories: aspects of language teaching (this category is present in both groups and comprises questions concerning materials for students, materials for one's own development and questions concerning teaching approaches and techniques), general education issues (this category is present only in group A) and linguistic issues (this category is present only in group B). In the analysed sample there are no questions that could be labelled as relating to personal aspect of one's growth. Interestingly, in both groups questions received the greatest number of comments of all posts in the sample: in group A there were 27 questions and 222 comments altogether, while in groupB there were 24 questions and 205 comments.

Table 2. Questions asked in group A.

\begin{tabular}{|c|c|c|c|}
\hline Asking for advice/asking a question ${ }^{1}$ & Likes & Comments & Shares \\
\hline \multicolumn{4}{|l|}{ Aspects of language teaching } \\
\hline $\begin{array}{l}\text { 1. Posting a poster - types of reading } \\
\text { (intensive reading vs extensive reading) } \\
\text { Have you contemplated about this pic? }\end{array}$ & 41 & 19 & 4 \\
\hline
\end{tabular}

1 This column contains quotes from FB posts. The original grammar and spelling have been preserved. 


\begin{tabular}{|c|c|c|c|}
\hline Asking for advice /asking a question & Likes & Comments & Shares \\
\hline $\begin{array}{l}\text { 2. How do you teach reported speech in } \\
\text { context? }\end{array}$ & 31 & 21 & - \\
\hline $\begin{array}{l}\text { 3. Fresh ideas to introduce Past Simple to } \\
\text { young learners and teenagers? }\end{array}$ & 21 & 16 & 1 \\
\hline $\begin{array}{l}\text { 4. Activities to teach Present Perfect Tense } \\
\text { to intermediate level ESL students? }\end{array}$ & 20 & 15 & 5 \\
\hline $\begin{array}{l}\text { 5. Good book to improve my academic } \\
\text { writing? }\end{array}$ & 22 & 13 & 1 \\
\hline $\begin{array}{l}\text { 6. Short course (one week or so) on English } \\
\text { methodology this summer in the UK; a } \\
\text { webpage I can have a look at? }\end{array}$ & 11 & 13 & - \\
\hline $\begin{array}{l}\text { 7. Fun/creative ways to teach conditional } \\
\text { type } 2 \text { ? }\end{array}$ & 14 & 11 & - \\
\hline $\begin{array}{l}\text { 8. Books with sounds to teach English to } \\
\text { a 4-year-old boy who has never learnt } \\
\text { English? }\end{array}$ & 10 & 10 & 1 \\
\hline $\begin{array}{l}\text { 9. What might be the objectives of a } \\
\text { listening lesson? }\end{array}$ & 7 & 10 & - \\
\hline $\begin{array}{l}\text { 10. What do you have printed on the walls of } \\
\text { your classroom? }\end{array}$ & 5 & 9 & - \\
\hline $\begin{array}{l}\text { 11. Highly Immersive Programme to make } \\
\text { students learn English informally. I'm } \\
\text { thinking of playing some songs and } \\
\text { encourage Ss to guess the lyrics and } \\
\text { then sing them aloud? Is "Perfect" a } \\
\text { suitable song? }\end{array}$ & 5 & 9 & 1 \\
\hline $\begin{array}{l}\text { 12. What materials to use to conduct an } \\
\text { interesting lesson on homophones? }\end{array}$ & 14 & 8 & - \\
\hline $\begin{array}{l}\text { 13. How to motivate my students for a } \\
\text { reading comprehension lesson? }\end{array}$ & 13 & 8 & - \\
\hline $\begin{array}{l}\text { 14. When lesson planning do you } \\
\text { recommend making a plan for the week } \\
\text { or each day? Lessons are "circle time" of } \\
10-15 \text { min (pre-school teachers). }\end{array}$ & 2 & 7 & - \\
\hline
\end{tabular}




\begin{tabular}{|c|c|c|c|}
\hline Asking for advice /asking a question & Likes & Comments & Shares \\
\hline $\begin{array}{l}\text { 15. Nursery rhymes for the } 4 \text { seasons to } \\
\text { teach children aged } 2-5 \text {; copyright free } \\
\text { materials and available online needed; } \\
\text { write a few rhymes and share them with } \\
\text { me! }\end{array}$ & 5 & 6 & 1 \\
\hline $\begin{array}{l}\text { 16. How to make the class interactive with } \\
\text { the lesson "parallelism"? }\end{array}$ & 9 & 6 & - \\
\hline $\begin{array}{l}\text { 17. How to present a lesson on Internet } \\
\text { slang to low-intermediate students? }\end{array}$ & 18 & 6 & - \\
\hline $\begin{array}{l}\text { 18. Creating a unit for 9th grade: artworks } \\
\text { and the representation of historical } \\
\text { events in the United States. } \\
\text { 19. I would like to test project-based } \\
\text { learning. Ss will have to choose and } \\
\text { work on an artwork to present it to the } \\
\text { class as part of an exhibition. Ideas for } \\
\text { the works of art and their handling? }\end{array}$ & 4 & 4 & - \\
\hline $\begin{array}{l}\text { 20. What different approaches to language } \\
\text { teaching do you know (for example PPP, } \\
\text { TBL)? Which one is the most useful? }\end{array}$ & 1 & 4 & - \\
\hline $\begin{array}{l}\text { 21. How to make a big scale activity (game) } \\
\text { for kids about dental hygiene? }\end{array}$ & 1 & 3 & - \\
\hline $\begin{array}{l}\text { 22. Need to evaluate students' speaking } \\
\text { skills; no time to do it in class } \\
\text { individually; record a video or audio in } \\
\text { groups of 3; can you share a fun activity } \\
\text { to perform? }\end{array}$ & 2 & 3 & - \\
\hline $\begin{array}{l}\text { 23. Different forms to work with music in } \\
\text { the class? }\end{array}$ & 9 & 2 & - \\
\hline $\begin{array}{l}\text { 24. Games or activities on which I can } \\
\text { practice or show multicultural } \\
\text { competencies and the cultural diversity } \\
\text { to } 19-21 \text { years olds? }\end{array}$ & 2 & 2 & - \\
\hline $\begin{array}{l}\text { 25. A good method or technique to teach } \\
\text { recount text to the beginners? }\end{array}$ & 7 & - & 2 \\
\hline
\end{tabular}




\begin{tabular}{|l|l|l|l|}
\hline Asking for advice /asking a question & Likes & Comments & Shares \\
\hline $\begin{array}{l}\text { 26. A lesson to my classmates about } \\
\text { adjectives (order and comparison). Any } \\
\text { games? Any ideas? }\end{array}$ & 9 & - & 1 \\
\hline $\begin{array}{l}\text { 27. I'd like to teach my 16 years students } \\
\text { something about English culture, } \\
\text { focussing in particular on Henry and } \\
\text { Meghan royal wedding (...) Any ideas? }\end{array}$ & 4 & - & - \\
\hline $\begin{array}{l}\text { General education issues } \\
\text { 28. 5-year-old boy in first grade. Homework: } \\
\text { unscramble the words with a school } \\
\text { objects vocabulary. The boy is just } \\
\text { beginning to read and write. }\end{array}$ & 29 & 17 & - \\
\hline
\end{tabular}

Table 3. Questions asked in group B.

\begin{tabular}{|l|l|l|l|l|}
\hline \multicolumn{2}{|l|}{ Asking for advice/Asking a question ${ }^{2}$} & Likes & Comments & Shares \\
\hline \multicolumn{2}{|l|}{ Language teaching methodology issues } & 32 & 25 & - \\
\hline Books to improve teaching techniques? & 18 & 16 & - \\
\hline $\begin{array}{l}\text { Any interesting ideas to teach Oliver Twist } \\
\text { and Great Expectations at high school? }\end{array}$ & 3 & 13 & - \\
\hline $\begin{array}{l}\text { If you have the choice, what are the grades } \\
\text { that you will select to teach? }\end{array}$ & 18 & 12 & - \\
\hline $\begin{array}{l}\text { Ideas to teach adverbs of frequency? } \\
\text { Reading materials for beginners? }\end{array}$ & 15 & 11 & - \\
\hline $\begin{array}{l}\text { Short stories for ESLkids (pre-school first } \\
\text { graders); stories with simple vocabulary for } \\
\text { beginners? }\end{array}$ & 8 & 10 & - \\
\hline $\begin{array}{l}\text { I'm an English student at university } \\
\text { planning to teach English. Any suggestions } \\
\text { for teaching tips and skills? }\end{array}$ & 1 & 10 & - \\
\hline $\begin{array}{l}\text { How to prepare students for TOEFL exam? } \\
\text { Any tips? Any useful pages? }\end{array}$ & 54 & 9 & \\
\hline
\end{tabular}

2 This column contains quotes from FB posts. The original grammar and spelling have been preserved. 


\begin{tabular}{|c|c|c|c|}
\hline Asking for advice/Asking a question & Likes & Comments & Shares \\
\hline $\begin{array}{l}\text { Books or references about Suggestopedia, } \\
\text { the use of technology, Community Language } \\
\text { Learning? }\end{array}$ & 6 & 9 & - \\
\hline Websites to learn phonics? & 8 & 8 & - \\
\hline $\begin{array}{l}\text { What kind of lessons do you suggest for } \\
\text { someone who would like to improve his } \\
\text { speaking skills? }\end{array}$ & 5 & 8 & - \\
\hline $\begin{array}{l}\text { Ways of proving the listening and speaking } \\
\text { of students in grade } 6 \text { and } 8 \text { ? }\end{array}$ & 3 & 6 & \\
\hline Can you suggest me a latest grammar book? & 4 & 6 & - \\
\hline $\begin{array}{l}\text { A mega project that should go on for an } \\
\text { entire term; activities for the project? }\end{array}$ & 6 & 5 & - \\
\hline $\begin{array}{l}\text { How to find pdf from New Basic Survival } \\
\text { Macmillan? }\end{array}$ & $\begin{array}{l}5 \\
\text { (reactions) }\end{array}$ & 5 & - \\
\hline $\begin{array}{l}\text { Literary pieces for dramatic monologue / } \\
\text { interpretative reading? }\end{array}$ & 4 & 4 & - \\
\hline How to establish a richness of the article? & - & 3 & - \\
\hline $\begin{array}{l}\text { Suggestions for teaching Ss to write a cover } \\
\text { letter? }\end{array}$ & 3 & 2 & - \\
\hline $\begin{array}{l}\text { How can I find English material to study } \\
\text { from it for teaching English but with no } \\
\text { common rights and attribution? }\end{array}$ & - & 1 & - \\
\hline $\begin{array}{l}\text { 2-day English Camp Tamil-speaking trainee } \\
\text { teachers who will be working in the state } \\
\text { sector; no IT, maybe electricity; activities } \\
\text { that would develop their teachingskills but } \\
\text { also student-centred learning activities; I'd } \\
\text { be particularly interested in the activity } \\
\text { which most struck a chord when you did } \\
\text { your own teacher training. }\end{array}$ & 3 & - & - \\
\hline $\begin{array}{l}\text { Websites to download some paper revision } \\
\text { for an adult who is learning English (He is } \\
\text { French)? }\end{array}$ & - & - & - \\
\hline \multicolumn{4}{|l|}{ Linguistic issues } \\
\hline Meaning of no 1 and no 2 ? & $\begin{array}{l}14 \\
\text { (reactions) }\end{array}$ & 16 & \\
\hline
\end{tabular}




\begin{tabular}{|l|l|l|l|}
\hline Asking for advice/Asking a question & Likes & Comments & Shares \\
\hline Meaning of shingles? & 9 & 23 & - \\
\hline $\begin{array}{l}\text { While writing address in a letter we don't } \\
\text { give a comma after "To"; why? }\end{array}$ & 1 & 3 & - \\
\hline
\end{tabular}

The analysed questions are varied: there is no single issue that dominates the discussion in either of the groups. Furthermore, they suggest a varied length of professional experience of those who pose them. The teachers who ask, for example, about the objectives of a listening lesson or books to improve their teaching techniques are probably new to the profession, while those who want to find fresh ideas on teaching Past Simple to young learners and teenagers or fun/creative ways to teach second conditional are likely to be old-timers.

The analysis of problems posted by the supposed novice teachers leads us to suspect that they lack basic knowledge of methodology and/or teaching skills. The question is whether this is due to the poor quality of training they had received or the fact that they were allowed to teach with no qualifications.

It should also be stressed that the teachers' queries include problems to which solutions can be found in methodology textbooks, and questions which can be adequately answered by experienced instructors, as well as unusual and unorthodox problems. It would be interesting to interview teachers with such an unconventional approach to developing their learners' skills about who or what motivates them to do so.

There are very few language questions in the analysed sample. However, one only needs to use the search term "meaning of" to find more linguistic issues that teachers in both groups struggle with. The three language questions in group B (Table 3, items 22, 23, 24) concern three different problems and therefore no general conclusions can be drawn about the linguistic needs of members of both groups.

The general education question (Table 2, item 27) is not connected with language teaching. However, language teachers need to know development characteristics of different age group to effectively choose and/or design activities and plan lessons. For that reason they should be able to assess whether unscrambling words (school objects vocabulary) is appropriate homework for a 5 -year-old boy who is just beginning to read and write.

As mentioned earlier, in both groups the questions received the greatest number of comments in the whole sample. The analysis of the comments is beyond the scope of this article, but it could reveal how useful these pieces of advice are, as well as how different or similar teachers' approaches to solving one problem are. 


\section{b) Links to websites}

Nowadays teachers are not restricted to the participation in offline training courses to pursue their professional development. A wide availability of online materials: articles, webinars, training films, means that teachers can improve their skills whenever and however they want. On the one hand this abundance offers teachers limitless development opportunities, on the other hand, however, it is easy to feel overwhelmed or lost while searching for the latest and mostvaluable sources of information. Turning to Facebook groups while looking for adequate materials might be a good idea, as the information that their members share is pre-selected and if someone is recommending, for example, a worksheet or an article, they might be of more usefulness.

In the analysed sample of posts there are links which take teachers to websites with articles they might use tobroaden their knowledge of language teaching methodology and refresh their teaching skills. In group B there are 23 such links and 18 of them were posted by the group administrator. Some of these pre-selected articles are more theoretically angled, e.g. item 4 in Table 5, and some suggest practical solutions, e.g. item 22 or 12 in Table 4. Collaborative learning is the issue that appears in both groups, and in group B it was highly popular: it received 54 likes (perhaps due to the fact that it was free and ELT Journal usually offers only paid access).

Table 4.Links to websites in group B.

\begin{tabular}{|l|l|l|l|l|}
\hline \multicolumn{2}{|l|}{ Link to website/Article title } & Likes & Comments & Shares \\
\hline \multicolumn{2}{|l|}{ Posts shared by the group administrator } & 29 & - \\
\hline $\begin{array}{l}\text { www.tes.com - What does an inclusive } \\
\text { classroom really look like? }\end{array}$ & 15 & 2 & - \\
\hline $\begin{array}{l}\text { www.edutopia.org - Good News for } \\
\text { Teachers: Exercise Builds Brain Power, Too }\end{array}$ & 13 & 4 & - \\
\hline $\begin{array}{l}\text { www.fluent.com - 3 Exciting Ways the } \\
\text { Grammar-Translation Method Is Still Great } \\
\text { for Language Teaching }\end{array}$ & $\begin{array}{l}|l| \\
\text { www.teachthought.com - 10 reasons to Use } \\
\text { Inquiry-Base Learning in Your Classroom }\end{array}$ & 13 & 1 & - \\
\hline $\begin{array}{l}\text { www.teachthought.com - How To Teach } \\
\text { Students To Research Without Google }\end{array}$ & 11 & 1 & - \\
\hline $\begin{array}{l}\text { www.teachthought.com - Are Students } \\
\text { Doing Projects Or Learning Through } \\
\text { Project-Based Learning? }\end{array}$ & 10 & 4 & - \\
\hline
\end{tabular}




\begin{tabular}{|c|c|c|c|}
\hline $\begin{array}{l}\text { www.teachthought.com - Learning is } \\
\text { an experience. Everything else is just } \\
\text { information }\end{array}$ & 10 & 1 & - \\
\hline $\begin{array}{l}\text { www.edutopia.org - } 7 \text { Grading Tips for New } \\
\text { Teachers }\end{array}$ & 9 & 1 & 1 \\
\hline $\begin{array}{l}\text { Link to: www.eslspeaking.org-ESL } \\
\text { Speaking Lesson Plan Template }\end{array}$ & 9 & - & - \\
\hline $\begin{array}{l}\text { Link to: www.teachingchannel.org - How to } \\
\text { teach Ss the difference between cooperation } \\
\text { and collaborative learning }\end{array}$ & 8 & - & - \\
\hline $\begin{array}{l}\text { Link to: www.edutopia.org - The } 7 \\
\text { characteristics of a good leader }\end{array}$ & 6 & 1 & - \\
\hline $\begin{array}{l}\text { Www.clareseltcompendium.wordpress.com } \\
-5 \text { worksheet-free Vocab revision }\end{array}$ & 6 & - & \\
\hline $\begin{array}{l}\text { Www.teachingchannel.org 7-step } \\
\text { Vocabulary Strategy to Help You teach } \\
\text { Vocabulary to ESL(video) }\end{array}$ & 5 & 2 & - \\
\hline $\begin{array}{l}\text { https://www.teachingenglish.org. } \\
\text { uk/ - English language and medium of } \\
\text { instruction in basic education in low - and } \\
\text { middle-income countries: A British Council }\end{array}$ & 5 & - & - \\
\hline $\begin{array}{l}\text { WwW.edutopia.org - Using the Rule of Three } \\
\text { for Learning }\end{array}$ & 4 & - & - \\
\hline $\begin{array}{l}\text { www.teachthought.com - } 6 \text { Strategies for } \\
\text { Creating An Inquiry-Driven Classroom }\end{array}$ & 3 & - & - \\
\hline $\begin{array}{l}\text { www.eflieas.com-ESL/EFL speaking } \\
\text { activity: Role Play Debate }\end{array}$ & 2 & - & - \\
\hline $\begin{array}{l}\text { www.teachthought.com - } 31 \text { Surprising } \\
\text { Facts About Learning }\end{array}$ & 1 & - & - \\
\hline \multicolumn{4}{|l|}{ Post shared by other group members } \\
\hline $\begin{array}{l}\text { Www.davlae.co.uk - website full of free } \\
\text { resources }\end{array}$ & 10 & - & - \\
\hline $\begin{array}{l}\text { https://www.wikipedia.org/ - List } \\
\text { of countries by English-speaking } \\
\text { population }\end{array}$ & 4 & 2 & - \\
\hline
\end{tabular}




\begin{tabular}{|l|l|l|l|}
\hline $\begin{array}{l}\text { Www.linguapress.com - Reading for } \\
\text { advanced students on Stephen Hawking }\end{array}$ & 3 & 1 & - \\
\hline $\begin{array}{l}\text { Www.english.com - How to bring soft skills } \\
\text { into the business English classroom }\end{array}$ & - & - & - \\
\hline $\begin{array}{l}\text { www.coursers.org - Advertising a course: } \\
\text { Emerging Trends \& Technologies in the } \\
\text { Virtual K-12 Classroom }\end{array}$ & - & - & - \\
\hline
\end{tabular}

In group A there were only four such posts (see Table 5).

Table 5. Links to websites in group A.

\begin{tabular}{|l|l|l|l|}
\hline Link to website/Article title & Likes & Comments & Shares \\
\hline $\begin{array}{l}\text { https://academic.oup.com/eltj (ELT Journal) } \\
\text { - Collaboration }\end{array}$ & 54 & - & 31 \\
\hline $\begin{array}{l}\text { https://itdi.pro/itdihome/ (International } \\
\text { Teacher Development Institute) - Collaborative } \\
\text { learning }\end{array}$ & 8 & - & 1 \\
\hline $\begin{array}{l}\text { www.eflmagazine.com } \\
\text { A link to Moroccan English - } 7 \text { engaging } \\
\text { articles on language teaching methodology }\end{array}$ & 1 & - & - \\
\hline
\end{tabular}

These posts are rarely commented on (21 comments in group B and no comments in group A) and almost never shared, except from the free article on collaborative learning from ELT Journal (31 shares), but the teachers show their appreciation towards the content the links take them to by liking the posts (159 likes in group B and 69 likes in group A). A different question is how many teachers liked the post because they read the suggested article, and how many expressed their positive attitude only because they liked the title.

Group members also share links that take their colleagues to websites, websites with in-built blogs and blogs they created themselves ${ }^{3 .}$ In group A there are 25 such posts with 337 likes, 6 comments and 266 shares altogether while in group B one can find 14 similar links with 36 likes, 3 comments and no shares. Unlike links to external websites, links to websites and blogsmanaged by members direct people to more practical contents.

In group A the links take other group members, among others, to: a free book with texts to improve learners' grammar, free board games, bingo games, a treasure hunt, activities for one on

3 In order to ensure the anonymity of the group members the author of the article decided not to reveal the links. 
one tutoring, free printables, courses for teachers, e.g. The Profitable Organized English Teacher, lesson plans based on podcasts, lesson plans developing students' digital literacies and critical thinking skills, tools for creating own online courses, information on events, e.g. EFL TalksInternational Women's day, books written by the group members, etc. In group B, if the group members follow the links they will find, among others, lesson plans based on YouTube videos, homemade worksheets, teacher and language development courses, E-learning courses/Skype courses, purchasable board games and free board games, picture books designed for parents/teachers to read aloud with children, Skype lessons, focusing on listening and/or pronunciation, etc. The most popular post - 109 likes - was the one where its author offered other group members a free book with texts to improve learners' grammar. The second most popular one - 66 likes - was posted by the same author but this time group members were presented with two downloadable games to practise Past Simple. None of the posts in group B was as popular as the one with 109 likes. The most popular post here received only 9 likes and its author was "advertising" a lesson plan devoted to St Patrick's day.

As mentioned before, group A has more links to personal websites, websites with in-built blogs and blogs than group B which is probably caused by the fact that group A is almost three times as big as group B hence the greater likelihood of attracting visitors which is especially importantas some of them offer purchasable products and services. It should be stressed that contemporary consumers turn to social media with an increasing frequency to search for information and to make their purchasing decisions (Lempert 2006; Vollmer \& Precourt 2008, in: Mangold and Faulds 2009: 360).

The bigger the group, the greater the likelihood of people sharing the links and spreading the news to their friends and other professionals. A large number of shares might result in an even greater amount of traffic, i.e. customers interested in buying the offered products and services, and, if the website or blog is very popular, advertisers willing to cooperate with the owners.

\section{c) Posts shared from FB pages/groups}

In both groups their members shared posts from their personal Facebook pages, from Facebook pages belonging to institutions they work for, from Facebook pages whose contents they liked or from other Facebook groups. In group A there are 36 such posts including 22 posts which are shared from members'personal pages while in group B there are 19 similar posts including 7 posts which are shared from members' personal Facebook pages. The probable reason why there are three times as many posts from personal pages in group $\mathrm{A}$ is its larger size.

These shares from personal pages can be treated as a form of self-promotion and the bigger the group, the more people will see the link and visit the website. Just like with links to personal websites, a big volume of website traffic is likely to attract, for instance, advertisers, and some visitors can become customers. The links to personal posts in group A also received a greater number of likes and shares, i.e. 179 and 44 respectively, than links to similar posts in group B 37 and 4 respectively. 
Usually, such a post in both groups contains a link to a website with a theoretical article on language teaching, an article with practical teaching tips, a film explaining intricacies of the English language, a film with tips on how to, for instance, deal with anxiety, a filmpresenting real-life events with a question on how it could be used in a language classroom, a lesson plan, a worksheet, information about an event, a selection of interactive classroom tools, etc. Group members also share posts with a poster or a video illustrating a language aspect, a funny gif or ecard illustrating teacher's life.

The most popular post in group A was a link to a film about a boy who turned a subway platform into his therapy office - it received 102 likes. The group members were also asked how they would use it in their classrooms. The most popular link shared from a personal page was the one with a link to a YouTube film about a speaking challenge - it received 37 likes.

In group B the most popular post was the one with a film about a Japanese kindergarten with no walls titled Kids need a small dose of danger - it received 96 likes. The most popular link shared from a personal page was the one with an article on interactive tools such as pie simulator, countdown timer or a classroom timer.

\section{d) Motivational posters for teachers}

Praver and Oga-Baldwin (2008: 1) observe that the motivation level of the teacher is one of the most frequently overlooked aspects of second language acquisition. They further stress that teachers do not find it easy to maintain their intrinsic motivation to work with students due to such factors as, for example, the work environment or student response to instruction. It is no wonder then that members of both groups publish posters whose aim is to motivate and inspire their colleagues. The motivational posts received 584 likes, 35 comments and 134 shares.

In group B there are 11 posts with motivational and information contents; 6 of them were posted by the group administrator and their titles are as follows:

- Growth happens when you ...

- Great teachers do ...

- The purpose of education is (a quote by Robert M. Hutchins)

- What students remember most about teachers

- Types of student inquiry

- Every child needs a champion.

The first three posts in this category received a similar number of likes: 51,50 and 47 respectively which suggest that teachers need more than learning new teaching techniques or familiarizing themselves with the latest theories of language teaching. The remaining posters from this category can be divided into three groups:

- $\quad$ student-related posters

- How creativity gets killed

- Cultivating literacy by growing young readers 
- teacher-related posters

- Six traits of life changing educators

- $\quad$ Spring break for teachers

- general content

- The meaning of mothers in your life.

In group B there are four inspirational and informational posters - two of them are related to teachers' emotional needs:

- The day you really become a teacher. This post received a remarkable 283 likes which further corroborates the previous statement on teachers' emotional needs. This post was also shared by 83 and commented by 26 people.

- How integrated technology is in your classroom.

The other two might be related to any profession:

- a poster with a quote on feedback by Bill Gates,

- a poster with a quote by Nelson Mandela with a motivational text underneath on teaching and methodology.

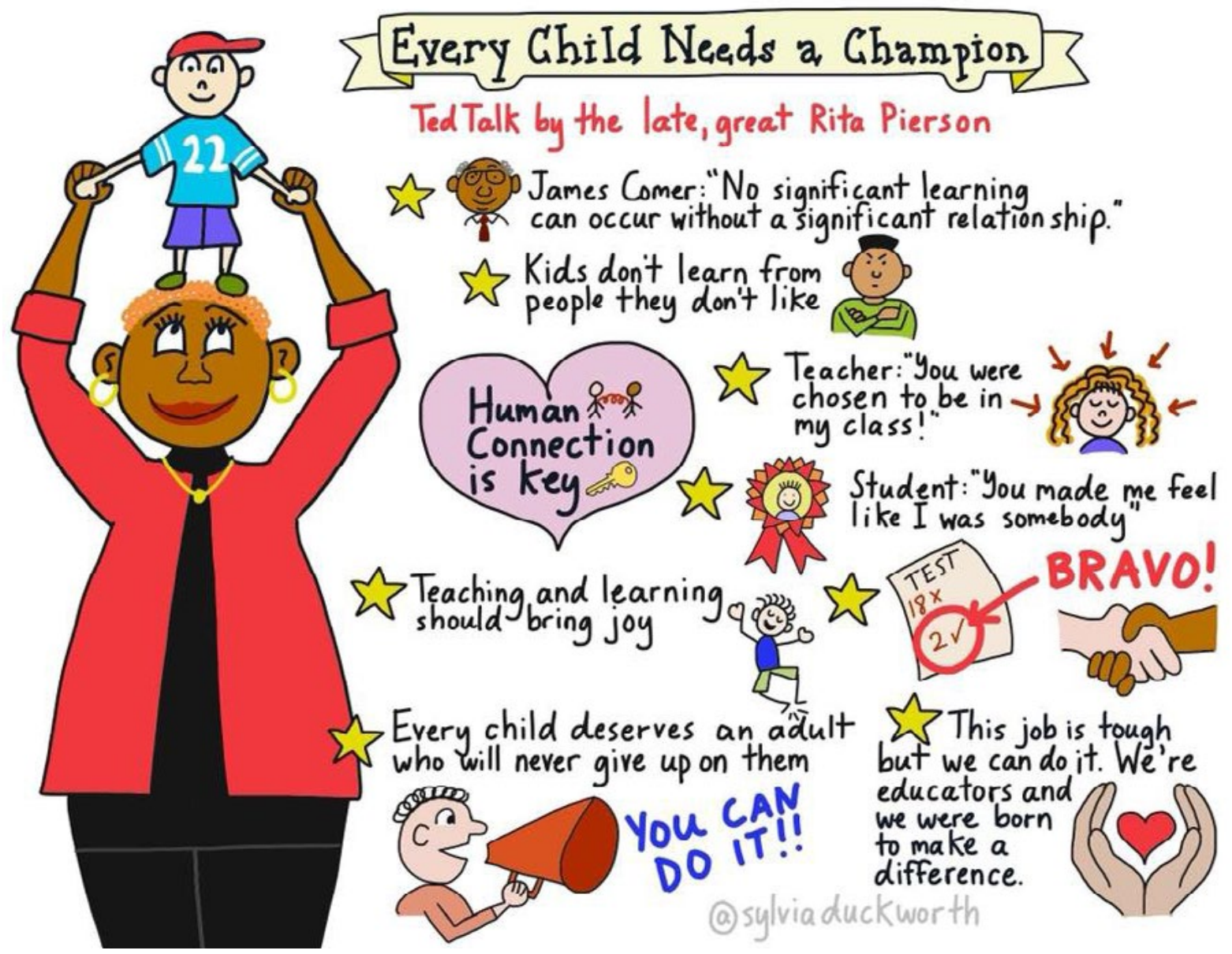

Fig. 1. Motivational poster from group B. 


\section{e) Looking for pen pals/partners}

Teaching English in an environment where students cannot put into practical use what they have learnt might be difficult. What is more, if students do not use the language, their skills will deteriorate.

In the analysed sample of posts there are 8 posts by people looking for pen pals for their students, conversational partner or project partners. The posts received 133 likes, 78 comments and 4 shares.

In group A there are 4 posts by people who wanted to find:

1. penfriends for students aged 11 so they could develop their writing skills. This post received the greatest number of likes and comments, i.e. 42 and 31 respectively. This indicates that the project was appreciated by the group members. This is possibly related to the fact that it is difficult to teach writing in a meaningful context, especially to young teenagers.

2. conversational partners for students 11-14 who want to improve their English through Skype interviews;

3. "snail mail" pen pals for non-native English speaking students aged 10/11;

4. pen pals for students aged $9 / 10$ years to discuss different types of food around the world.

One request for partners was posted by a person who wanted to cooperate with other teachers in an eTwinnig project about "the conquest of space through mythology and astrology". This post received only one like, perhaps due to the esoteric nature of the project.

In group B one post was written by a person who was searching for pen pals from different countries for Korean students aged 10-15. The second posts was by a member who was looking for partners to a project on renewable energy taking place in a Turkish vocational school. The third request was written by a teacher who wanted to get in touch with other teacherswho do "little" projects with kids to exchange ideas and the effects of their work. It was this post that received the greatest number of likes and comments, i.e. 30 and 17 respectively. This suggests there are teachers who work with children this way and would like to share their experiences.

\section{f) Questionnaires}

Facebook groups for teachers are an excellent arena for promoting one's or company's educational products and services. Additionally, the sheer number of members, their different teaching experiences and the educational settings they work in attract researchers who post: larger samples are a source of more data and provide a better picture for analysis. In the analysed samples of posts there are 5 questionnaires: 3 in group $\mathrm{A}$, and 2 in group $\mathrm{B}$.

All the questionnaires in group A were created with the help of GoogleDocs. The aim of the first questionnaire was to gather information on art, dance, games and music in different countries. The obtained data would be used to develop a curriculum for primary school teachers to broaden their awareness of cultural variety around the world. The second questionnaire was posted by a B.A. student who was researchingthe reception (the naturalness) of selected phrase and sentences by native 
speakers of English. The third questionnaire was posted by a student of industrial design who wanted to learn how often teachers of English use presenter devices and what their presenter habits are.

In group B the first questionnaire was also developed with the help of GoogleDocs and was devoted to the use of ICT in the language classroom. The second questionnaire in group B was created with the help of Facebook tools for creating polls. Its creator it wanted to see which course books English teachers found most interesting while working with adult language learners.

The number of questionnaires in the analysed sample is small but it is enough to use the search term "survey" to find more than 30 surveys in each group posted by, for example, professional researchers or BA or MA students.

\section{g) Videos}

Apart from sharing links to websites or post from other Facebook pages or groups, members of both groups share links to videos. Some of these links take group members to professional YouTube channels created either by an individual group member or by an organization, e.g. a publisher. Just like with links to members' own websites, the author of the article decided not to reveal the links in order to ensure the anonymity of the group members.

In these YouTube channels one can watch videos with teaching tips, e.g. how to plan group work effectively, how to conduct discussion activities, vocabulary lessons, e.g. how to use phrasal verbs or how to talk about fruit and vegetables (such lesson usually take place in real-life context, for example in New York or in a supermarket) grammar lessons based on Disney movies, a grammar lesson on English articles, etc.

There are also amateur videos showing lesson fragments, e.g. how to work with an interactive whiteboard, how to write complete answers to questions or amateur videos devoted to selected language aspects e.g. how to pronounce letter "a" in different words.Moreover, one can find a link to a YouTube playlist with a films devoted to most common mistakes in English, a film with a South-African sharing her views on the pros and cons of living in New Zealand, or a video with a song the aim of which is to help students remember gerunds and infinitives. A link to one's own websites, Facebook pages, YouTube channels or lessons can become a tool for self-promotion.

\section{h)Advertising events/courses}

Due to their large memberships with varied needs, Facebook groups can become an advertising board for different events and courses. The posts in group A received 134 likes, 6 comments and 14 shares while the only post in group B received neither of them.

In the analysed sample in group A there are three such posts:

- a link to a teaching course for non-native teachers in Russia. 124 people liked this post which might suggest how needed such courses are in certain parts of the world;

- a link to a sign-up form for VII Annual Round Table on Modern Approaches to Foreign Language Teaching in Tenjo, Columbia; 
- a link to a one-day workshop for teachers - Empowering English Teachers in Language Teaching in Lima, Peru.

In group B there is one post advertising an event devoted to best practices in teaching foreign children in primary and secondary education. The event was held in Milton Keynes.

\section{i) Language posters}

Apart from asking language questions, members of group Bpost posters which explain the meaning of language expressions (mostly vocabulary).

There are 16 such posts in group A; 13 posts contain one poster, one post contains 3 posters explaining the meaning of "for" and "since", another one contains 19 posters with different business expressions and yet another one contains 4 posters showing relations between family members. Members of group A greatly appreciate these posters, which is reflected in the number of likes they received: 514. The most popular one in terms of "likes" was the poster illustrating the meaning of prepositions with 90 likes (see Figure 2), and the least popular one was the poster explaining the meaning of the idiom "eye candy" (see Figure 3).

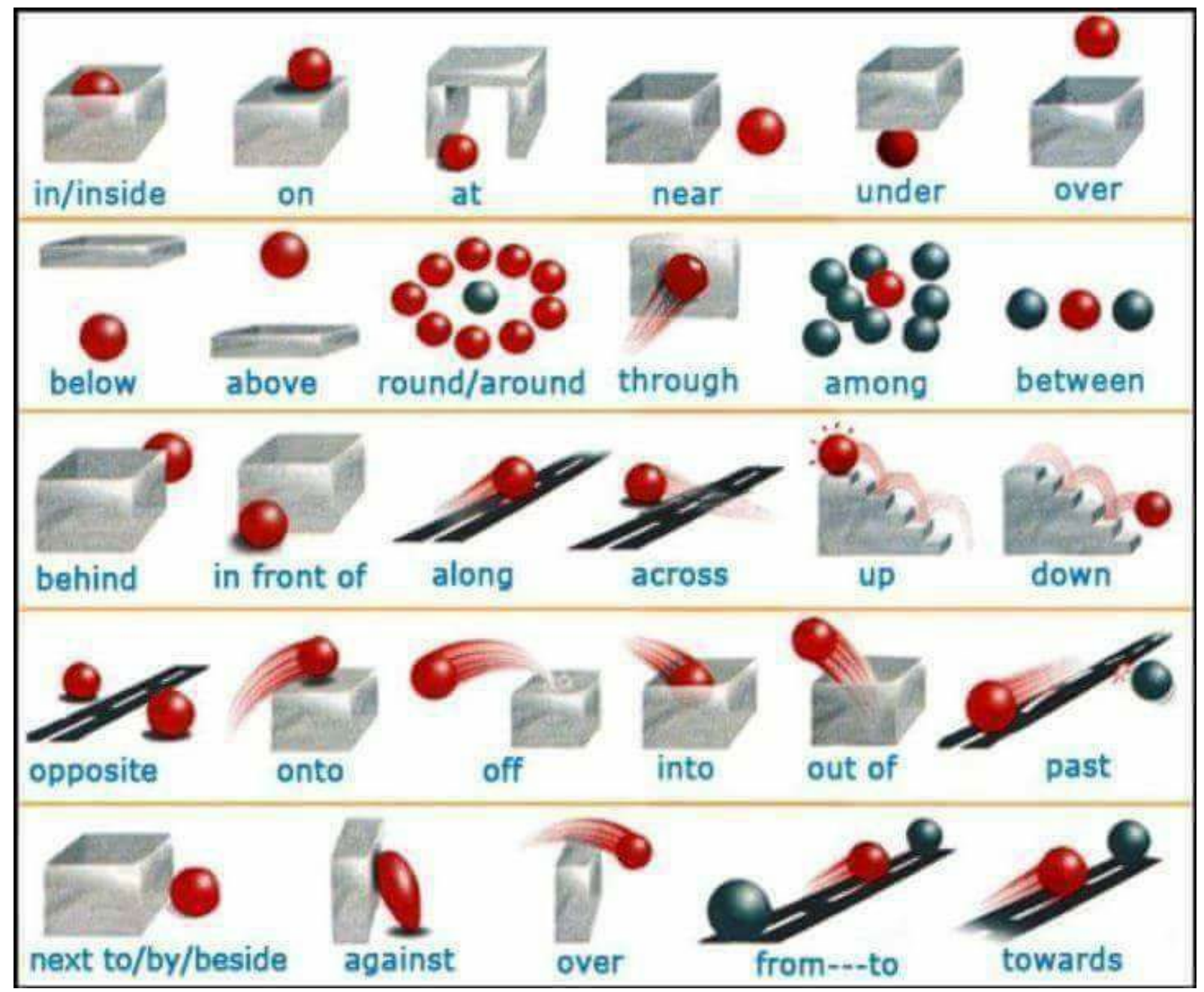

Fig. 2. Poster illustrating the meaning of prepositions of movement. 


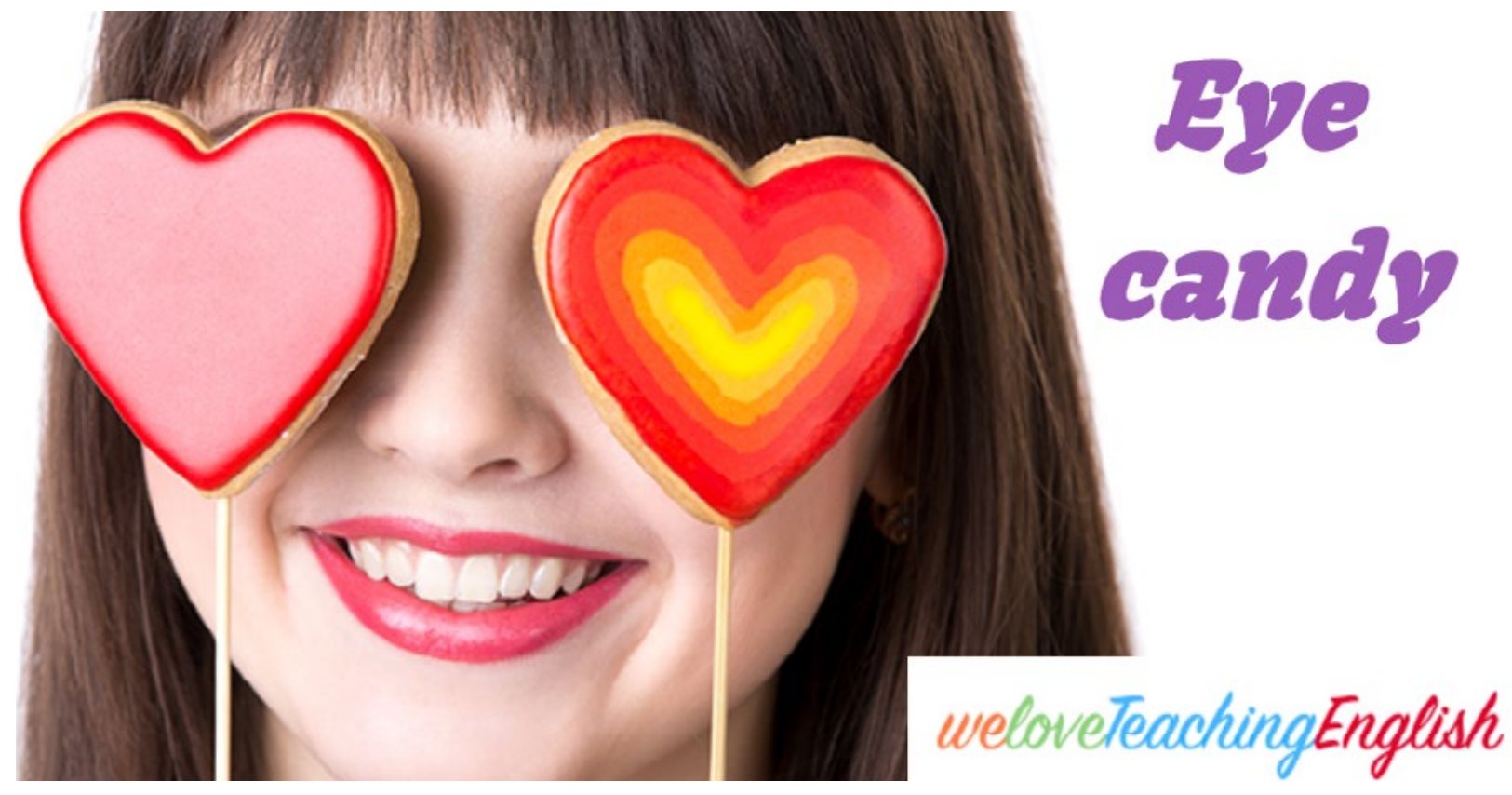

Fig. 3. Poster illustrating the meaning of the idiom eye candy 4 .

It would be interesting to analyse why these posts were so appreciated by the teachers: whether it is because teachers still struggle with similar issues or whether they would like to use them in their language classrooms. It is also intriguing that there are no similar posts in group $\mathrm{B}$. This might be due to the nature of the two groups' membership, but it is impossible to say for certain without more thorough examination.

\section{Conclusions}

The findings of the study show that members of both groups publish posts in which they ask how they could help their students, as well as those in which they discuss their own professional and personal needs. As for the teachers' professional needs, members of both groups show their appreciation not only towards practical solutions, but also towards the theoretical content suggested by others. The findings also show that, apart from creating their own personal learning networks in Facebook groups, their members treat them as arenas for promoting their products (e.g. books, worksheets, games, training videos, video lessons for students), services (e.g. training courses), or events (e.g. conferences or workshops). As mentioned before, the larger the group, the greater the likelihood of attracting visitors to one's personal website or blog and turning them into customers.

Interestingly, an insight into both groups has shown how a group administrator might affect the type of published content not only in terms of removing offensive posts and comments or moderating discussions, but most of all by promoting certain types of theoretical approaches to teaching or practical classroom solutions.

4 The poster was accompanied by the following text: "EYE CANDY means something beautiful to look at, pleasing to the senses". 
Similar studies, but on a larger scale, could be conducted by course developers. By observing a large and varied number of Facebook groups for teachers they would be able to redesign their curricula so as to adequately respond to teachers' theoretical and practical needs: it might be assumed that in an increased number of posts recurring issues will appear. Teachers could also be trained how to promote themselves in professional way in an online environment, i.e. how to create easy to navigate websites or record good quality films, or create professional event or conference advertisements, as some of the promotional materials in the analysed sample were not attractive enough to encourage people to buy a product or service. Course developers could also train language instructors how to design online games or interactive activities which were greatly appreciated by the members.

Finally, the analysis of the posts has revealed that language teachers need more than broadening their teaching skills and knowledge or being able to adequately respond to students' needs: they need to be constantly motivated, inspired and reassured that they are doing their job well.

\section{References}

Alrubail, Rusul. An Academic Use for Social Media, Edutopia, August 2017, https://www.edutopia. org/article/academic-use-social-media, [06.09.2018].

Amasha, Mohamed and Salem Alkhalaf. 2014. The Effect of using Facebook Markup Language (FBML) for Designing an E-Learning Model in Higher Education. International Journal of Research in Computer Science 4 (5).1-9.

Biglione, Kirk. What is WordPress?, WP Apprentice, January 2016, https://wpapprentice.com/ blog/what-is-wordpress/, [13.09.2018].

Bissessar, Charmaine S. 2014. Facebook as an Informal Teacher Professional Development Tool. Australian Journal of Teacher Education 39(2). 121-135. doi: 10.14221/ajte.2014v39n2.9.

Black, Tiffany. Using Facebook Groups, Lifewire, 30 Septemeber 2017, https://www.lifewire.com/ facebook-groups-4103720 [27.03.2018].

Britland, Matt. 2012. Social media for schools: a guide to Twitter, Facebook and Pinterest, The Guardian, 26 July 2012, https://www.theguardian.com/teacher-network/2012/jul/26/socialmedia-teacher-guide [27.03.2018].

Carpenter, Jeffrey P. and Daniel G. Krutka. 2015. Social Media In Teacher Education. In: M.L. Niess and H. Gillow-Wiles (eds.), Handbook of Research on Teacher Education in the Digital Age. Hershey, PA: Information Science Reference. 28-54.

Diaz-Maggioli, Gabriel. 2003. Professional Development for Language Teachers. ERIC Digests EDO-FL-03-03.

Faryadi, Qais. 2017. Effectiveness of Facebook in English Language Learning: A Case Study. Open Access Library Journal4: e4017.1-11.doi: 10.4236/oalib.1104017.

Foreman, Curtis.10 Types of Social Media and How Each Can Benefit Your Business, Hootsuite June 2017, https://blog.hootsuite.com/types-of-social-media/, [06.09.2018]. 
Gibson, Ryan O. Using social media as a language learning tool, The Guardian, April 2012, https:// www.theguardian.com/teacher-network/teacher-blog/2012/apr/10/language-teaching-social-media, [06.09.2018].

Gil, Paul. What Is Twitter \& How Does It Work?, Lifewire, February 2018, https://www.lifewire. com/what-exactly-is-twitter-2483331, [13.09.2018].

Greenhow, Christine, Diana Campbell, Sarah Galvin, andEmilia Askari. 2018. Social Media in Teacher Professional Development: A Literature Review. In E. Langranand and J. Borup (eds.), Proceedings of Society for Information Technology \& Teacher Education International Conference, 2256-2264. Washington, D.C., United States: Association for the Advancement of Computing in Education (AACE).

Gunelius, Susan. Is Tumblr the Right Blogging Tool for You, Lifewire, August 2018, https://www. lifewire.com/tumblr-overview-for-bloggers-3476387, [13.09.2018].

Heath,Alex. Facebook just introduced the biggest change since the 'Like' button, Business Insider, 24 February 2016, http://www.businessinsider.com/facebook-reactions-launch-globally2016-2?IR=T [27.03.2018].

Halizah, Omar, Mohamed Amin Embi and Melor MdYunus. 2012. ESL Learners' Interaction in an Online Discussion via Facebook. Asian Social Science 8(11). 67-74. doi: http://dx.doi. org/10.5539/ass.v8n11p67.

Hoskins, Lexie. Why should teachers use social media for professional development?, Cambridge Assessment. International Education, November 2015, http://blog.cambridgeinternational. org/why-should-teachers-use-social-media-for-professional-development/ [06.09.2018].

Iannone, Pablo A. 2017. Seeking Balance: Philosophical Issues in Globalization and Policy Making. Abingdon/New York: Routledge.

King, Marissa. Social Media Posts as Exemplars, Edutopia, July 2017, https://www.edutopia.org/ blog/social-media-posts-exemplars-marissa-king, [06.09.2018].

Lantz-Andersson,Annika, Louise Peterson, Thomas Hillman, Mona Lundin and Annika Bergviken Rensfeldt. 2017. Sharing repertoires in a teacher professional Facebook group. Learning, Culture and Social Interaction, 15. 44-55. doi: https://doi.org/10.1016/j.lcsi.2017.07.001.

Manca, Stefania and Maria Ranieri. 2014. Teachers' professional development in online social networking sites. In: J. Viteli \& M. Leikomaa (eds.), Proceedings of EdMedia 2014 - World Conference on Educational Media and Technology, 2229-2234. Association for the Advancement of Computing in Education (AACE): Tampere, Finland..

Mangold, Glynn W. and David J. Faulds. Social media: The new hybrid element of the promotion mix. Business Horizons, 52. 357-365. doi: 10.1016/j.bushor.2009.03.002.

Moreau, Elise. What Is Pinterest? An Intro to Using the Social Image Platform, Lifewire, September 2018, https://www.lifewire.com/how-to-use-pinterest-3486578, [13.09.208].

Nations, Daniel. What Is LinkedIn and Why Should You Be on It?, Lifewire, September 2018, https://www.lifewire.com/what-is-linkedin-3486382, [13.09.208]. 
Pappas, Christopher. The Facebook Guide For Teachers, eLearning Industry, 28 July 2013, https:// elearningindustry.com/the-facebook-guide-for-teachers [30.03.2018].

Prichard, Caleb. 2013. Using Social Networking Sites as a Platform for Second Language Instruction. TESOL Journal 4.4. 752-758. doi: https://doi.org/10.1002/tesj.113.

Rouse, Margaret. Facebook "Like" button, WhatIs.com?, August 2010, http://whatis.techtarget. com/definition/Facebook[27.03.2018].

Rouse, Margaret. Social media, WhatIs.com?, September 2016, https://whatis.techtarget.com/ definition/social-media [06.09.2018].

Rouse, Margaret. Facebook, WhatIs.com?, August 2014, https://whatis.techtarget.com/definition/Facebook [27.03.2018].

Santos, Mariana and Simon Rogers. How Facebook became the world's biggest social network animation, The Guardian, 15 May 2012,https://www.theguardian.com/news/datablog/video/2012/may/15/facebook-biggest-social-network-animation [26.03.2018]

Van Bommel, Jorryt and Yvonne Liljekvist. 2015. Facebook and mathematics teachers' professional development: Informing our community. In: K. Krainer andN. Vondrová (eds.), CERME 9 - Ninth Congress of the European Society for Research in Mathematics Education: Proceedings of the Ninth Congress of the European Society for Research in Mathematics Education. 29302936.

van Gilder Cooke, S. 2011. Walls Have Eyes: How Researchers Are Studying You on Facebook. TIME. Accessed at: http://content.time.com/time/business/article/0,8599, 2099409,00. html?iid=sr-link3 [27.03.2018].

Velestianos, George. 2016. Social Media in Academia. Networked Scholars. New York: Routledge.

Using Facebook in your teaching. 2018. Queen Mary University of London, E-Learning Unit. https://elearning.qmul.ac.uk/enhancing-your-teaching/using-social-media/using-facebook-in-your-teaching/ [26.03.2018].

Willson, Jeffrey L. Flipboard (for Android). PCmag, March 2017, https://www.pcmag.com/article2/0,2817,2406226,00.asp, [13.09.2018].

Xodabande, Ismail. 2017. The effectiveness of social media network telegram in teaching English language pronunciation to Iranian EFL learners. Cogent Education 4(1). 1-14. doi: https://doi. org/10.1080/2331186X.2017.1347081.

Yu, Li-Tang. 2014. A case study of using Facebook in an EFL English writing class: The perspective of a writing teacher. JALT CALLSIG: Forum 10 (3). 189-202.

100 Ways To Use Facebook In Education. 2017. Teach thought. https://www.teachthought.com/ technology/100-ways-to-use-facebook-in-education-by-category/[26.03.2018]. 